\title{
Applicability of IFRS in Vietnam stock exchange listed companies: Perspective from Theory of Planned Behavior
}

\author{
Nguyen Thi Ngoc Diep ${ }^{1 *}$ \\ ${ }^{1}$ Ho Chi Minh City Open University, Vietnam \\ *Corresponding author: diep.ntn@ou.edu.vn
}

\section{ARTICLE INFO}

DOI:10.46223/HCMCOUJS. econ.en.11.1.1237.2021

Received: October $27^{\text {th }}, 2020$

Revised: January $6^{\text {th }}, 2021$

Accepted: January $18^{\text {th }}, 2021$

Keywords:

IFRS, ability of IFRS adoption
ABSTRACT

The research, based upon data collected from 273 enterprises, uses the Theory of Planned Behavior (TPB) to identify and estimate the degree to which factors the ability to apply IFRS in listed nonfinancial enterprises has been affected. Through Exploratory Factor Analysis (EFA) and multivariate linear regression approach, the research proves that there are four factors placing impacts on IFRS adoption in listed companies in Vietnam. Those are management's attitude, costs, economic integration, accounting staff's knowledge and skills. The research results are the foundation for businesses to be fully prepared for the favorable and successful application of IFRS. In addition, the results of this study are also useful references for policy-making agencies and professional associations in promoting IFRS application in Vietnam the next time.

\section{Introduction}

International accounting integration is always a challenging process (Christopher \& Parker, 2016). The implementation of IFRS (International Financial Reporting Standards) in Vietnam has been constrained due to economic, educational, political and legal conditions (Tran, 2016). Furthermore, the IFRS are basically built on Anglo - Saxon model (Anglo-Saxon model of corporate governance) and are principle-based, and as a consequence, the standards are, culturally and practically, not easily adapted in Vietnam. The project on application of financial reporting standards in Vietnam (Decision No. 345/QD-BTC on March 16, 2020 - Ministry of Finance) confirms the determination to apply these standards in financial reporting in Vietnam. The main business entities which are considered to have the abilities and conditions and to be encouraged to apply IFRS voluntarily in the period of 2022 to 2025 are listed companies. Can those companies apply IFRS? To what degree should they be involved?

\section{Theoretical and hypothetical basis}

\subsection{Theory of Planned Behavior - TPB}

The Theory of Planned Behavior (Ajzen, 1991) supposes that any behavior is affected directly by behavioral intentions. The more salient the intentions are the more possibility for according behaviors we have.

The main purpose of TPB is to explain human behaviors, not for predictions only, so according to the TPB, behavioral intentions are determined by three factors: attitude toward the behavior, subjective norm concerning the behavior, and perceived behavioral control. Attitude toward the behavior is assumed to be a function of readily accessible beliefs regarding the 
behavior's likely consequences, termed behavioral beliefs; the subjective norm is the expectation or subjective probability that a given referent individual or group (e.g., friends, family, spouse, coworkers, one's physician or supervisor) approves or disapproves of performing the behavior under consideration; perceived behavioral control is concerned with the presence of factors that can facilitate or impede the performance of the behavior, this is the factor that encourages or discourages the behavior.

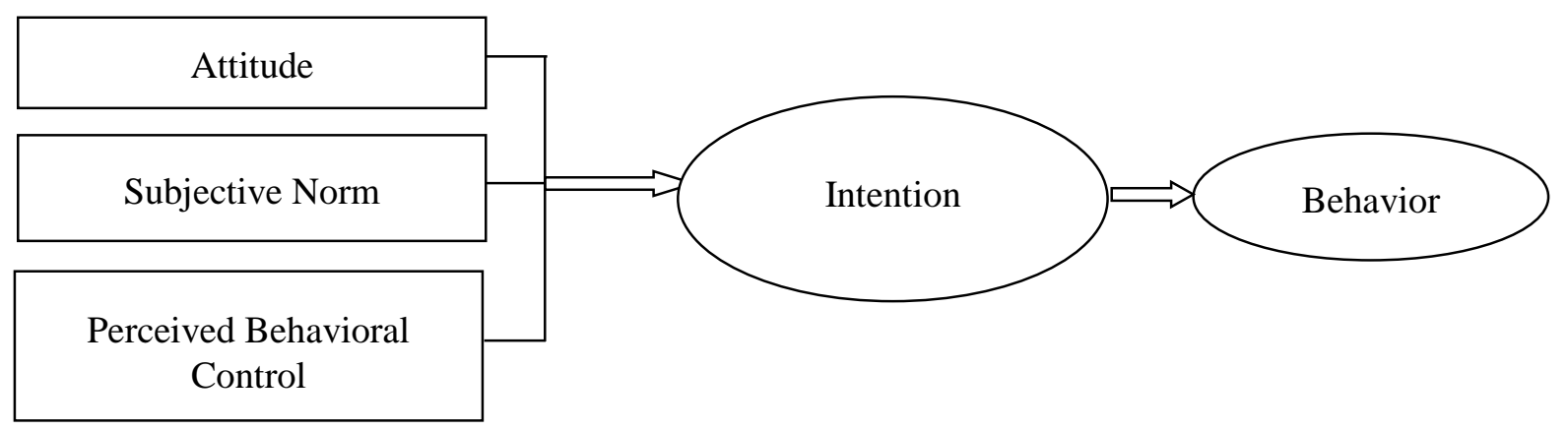

Figure 1. The Theory of Planned Behavior (Ajzen, 1991)

\subsection{Research model}

Based on the results of the research of Djatej, Zhou, Gorton, and McGonigle (2012) and Simegn (2015), as well as the qualitative research by interviewing experts, the authors generalize the factors affecting the possibility to apply IFRS in listed companies as follows.

Manager attitudes: Rogers (2010) assumed that the pioneers in innovation are the agents of change in any organization. Therefore, the change in attitudes of those agents is essential for applying changes. In his research on manager attitudes in India and Australia, Bhattacharyya (2014) found that manager attitudes positively affect the decisions in reporting sustainable development. Manager attitudes also play an important role in providing better conditions for applying IFRS in organizations (Bananuka, Kadaali, Mukyala, Muramuzi, \& Namusobya, 2019). As a consequence, the hypothesis is:

H1: Manager attitudes and the possibility to apply IFRS have a relationship in the same direction

Costs: Tyrrall, Woodward, and Rakhimbekova (2007) proves that only 54\% of the interviewed and questioned people think that adopting IFRS in Kazakhstan is a costly process. All the questioned people point out the costs relating to the implementation of IFRS such as staff training, accounting software adjustment, cost of new accounting documents and consulting services. In agreement with Tyrrall et al. (2007), the research of Bassemir (2018) identifies the need for changing IT systems, training and developing the workforce are potential challenges in applying IFRS in private enterprises. Boateng, Arhin, and Afful (2014) conduct a survey on 18 professional accountants from listed companies in Ghana, questioning them about the pros and cons of applying IFRS for companies in Ghana. The research proves that the lack of qualified staff and cost of operation are the big challenges in applying IFRS. Bui, Chuc, and Le (2020) have a survey of 20 experts, asking them about the benefits and challenges in applying IFRS in Vietnam. Their research demonstrate that the high cost in applying IFRS mainly caused by the cost of hiring consultants, as their accountants are not always qualified in IFRS; the cost of recruiting, training and developing the workforce for IFRS, the expenses for building and maintenance of IT system for preparing financial statements under IFRS; the language barrier is also an obstacle, for people in Vietnam have to translate IFRS from English to Vietnamese, the explanation of similarities in terms and concepts. So, the hypothesis is: 


\section{H2: Cost and possibility to apply IFRS have an opposite relationship}

Economic integration: Business transactions are becoming more and more complicated and the process of recognizing and reporting them goes the same way, national accounting standards turn to be inadequate to meet the requirements of users (Choi \& Meek, 2008; Judge, Li, \& Pinsker, 2010). Lasmin (2011)) mention that the opening of the economy creates the pressure of imitation, affecting the decision to apply IFRS in emerging economies. Besides, Nguyen and Nguyen (2012) suppose that the increasing number of foreign investors is one of the main factors for Vietnam to apply IFRS. Kossentini and Othman (2014) point out that in the emerging economies, the more globalized and integrated they are, the stronger the tendency they wish to apply IFRS. Oppong and Aga (2019) suppose that globalization in economic activities urges the reorganization of them to comply with international accounting standards. Along with that, transparent and comparable financial reports are the ground for enterprises in their seek for foreign direct investment and also enforcement of their globally competitive positions. So, the hypothesis is:

H3: Economic integration and the possibility to apply IFRS have a relationship in the same direction

Accountants' ability: When the international accounting standards are built on principles, the possibility for them to be practically applied depends largely on accountants' ability (Choi \& Meek, 2008). Countries with a less-developed education system may find the transition to IFRS more costly in comparison with countries with a better education system (Shima \& Yang, 2012). Misırlığlu, Tucker, and Yükseltürk (2013) had a survey in Turkey and proved that IFRS could not be applied due to limited ability in accounting. Having the same belief, Ha and Nguyen (2018); Bananuka et al. (2019) use accountants' ability as an explanatory variable. A limited level of education will be an obstacle in applying IAS/IFRS. So, the hypothesis is:

\section{direction}

H4: Accountants' ability and the possibility to apply IFRS have a relationship in the same

Consequently, there are four factors that affect the possibility to apply IFRS in listed companies in the Vietnam stock market (Figure 2).

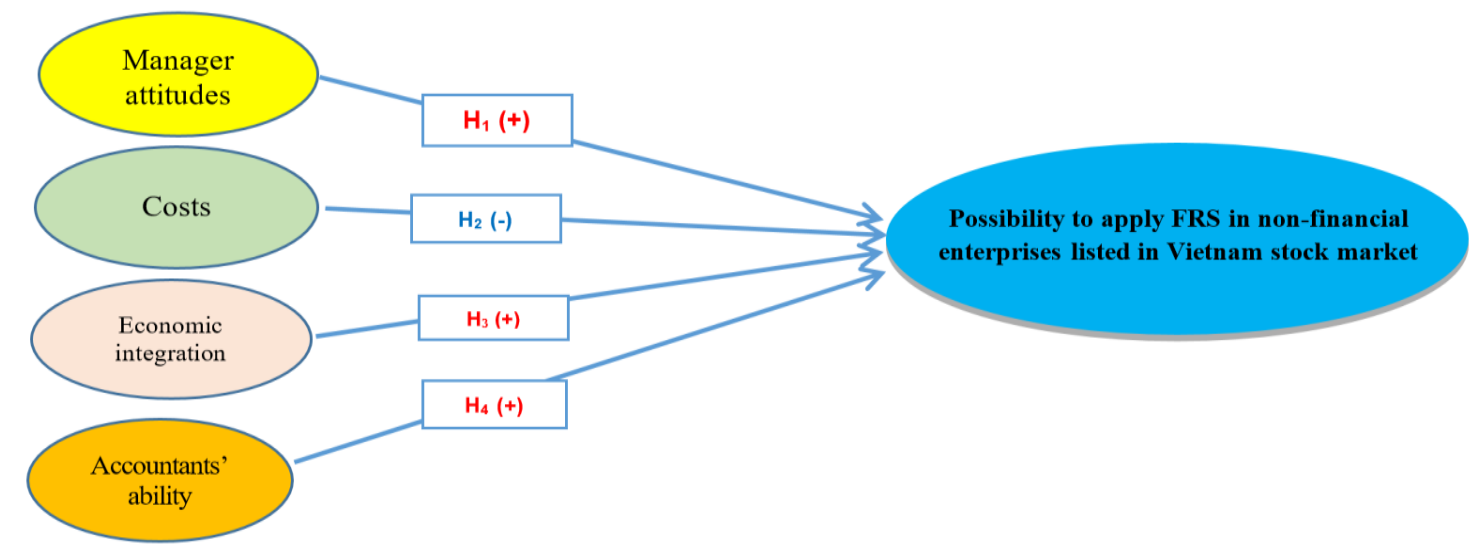

Figure 2. Research model

\section{Research methods}

To achieve the research's goals, the author use the deductive research approach, that is to be based on former theories and results of qualitative research by interviewing 10 experts, among them are the persons representing governmental agencies from which accounting standards are 
issued, members of IFRS translation board, accountants who are experienced in preparing financial reports under IFRS or have good knowledge in IFRS, auditors with experience in auditing IFRS compliant financial reports, lecturers with experience in teaching and studying IFRS. In combination with the methods mentioned above, the author also uses the inductive approach simultaneously for verification. The qualitative results are used to ignore dispensable factors and indicators, as well as the basis for adding new factors and indicators that are suitable for the context and conditions in Vietnam. Supported with the results from Simegn's research (2015) and using the qualitative method by interviewing experts, the author proposes the model with 4 factors that affect the possibility to apply IFRS in listed companies in the Vietnam stock market. The factors are manager attitudes; costs; the need to integrate into the global economy; accountants' ability.

In the next step, the author conduct surveys with questionnaires which have 24 observed variables (19 independent variables and 5 dependent ones) and are measured by Likert's scale in which the fifth choice is "completely agree", the 4th is "agree", the $3 \mathrm{rd}$ is "not decided", the 2nd is "disagree" and the 1st is "completely disagree". The data is collected by Google form sent directly to people surveyed, who are managers and accountants in Vietnam Stock Market listed companies. The number of companies with a direct response or through Google form is 362. After being checked, there are 273 survey sheets with sufficient information to be analyzed.

Cronbach's Alpha indicator is used for reliability analysis with SPSS 22.0. After that, coherent scales are verified once more with explanatory factor analysis (EFA) for necessary adjustments. Person correlation analysis is used to test the relationship between the scales and multivariate regression analysis to examine the differences between the variables. Furthermore, the author also implements the analysis of variance (ANOVA) to compare means of the populations from the 2 groups of IFRS - applied listed companies and non - IFRS ones in consideration of factors that affect the possibility to apply IFRS.

The scales were formed based on previous studies and experts' consultation (Table 1).

\section{Table 1}

Summary of scales

\begin{tabular}{|c|c|c|}
\hline Factors & Observed variables & Citation \\
\hline \multirow{4}{*}{$\begin{array}{l}\text { Manager } \\
\text { attitudes }\end{array}$} & $\begin{array}{l}\text { MA1: Managers fully support the IFRS application } \\
\text { roadmap, which positively affects the ability to apply } \\
\text { IFRS }\end{array}$ & Ha and Nguyen (2018) \\
\hline & $\begin{array}{l}\text { MA2: Managers are aware of the benefits when } \\
\text { applying IFRS, which positively affects their ability to } \\
\text { apply IFRS }\end{array}$ & $\begin{array}{l}\text { Djatej et al. (2012); Simegn, } \\
\text { (2015); Boumediene, } \\
\text { Zarrouk, and Tanazefti } \\
\text { (2016) }\end{array}$ \\
\hline & $\begin{array}{l}\text { MA3: Administrators are aware of the pressure of } \\
\text { globalization to push businesses to apply IFRS }\end{array}$ & \multirow[b]{2}{*}{$\begin{array}{l}\text { Bananuka, Tumwebaze, } \\
\text { Musimenta, and Nuwagaba } \\
\text { (2019) }\end{array}$} \\
\hline & $\begin{array}{l}\text { MA4: The manager is determined to build a budget, } \\
\text { strategy for the IFRS application roadmap, which has } \\
\text { a positive effect on the ability to apply this system of } \\
\text { accounting standards }\end{array}$ & \\
\hline Costs & $\begin{array}{l}\text { C1: It is quite expensive to invest in improving the } \\
\text { software and information systems in the process of } \\
\text { applying IFRS }\end{array}$ & $\begin{array}{l}\text { Boumediene et al. (2016), } \\
\text { Al-Absy and Ismail (2019) }\end{array}$ \\
\hline
\end{tabular}




\begin{tabular}{|c|c|c|}
\hline Factors & Observed variables & Citation \\
\hline & C2: The cost of IFRS training for accountants is high & $\begin{array}{l}\text { Boumediene et al. (2016), } \\
\text { Al-Absy and Ismail (2019) }\end{array}$ \\
\hline & $\begin{array}{l}\text { C3: Cost of consulting services initially affects the } \\
\text { implementation of IFRS }\end{array}$ & Al-Absy and Ismail (2019) \\
\hline & $\begin{array}{l}\text { C4: Recruiting highly qualified accountants to meet } \\
\text { the needs of applying IFRS is very difficult }\end{array}$ & Bui et al. (2020) \\
\hline \multirow{5}{*}{$\begin{array}{l}\text { Economic } \\
\text { integration }\end{array}$} & $\begin{array}{l}\text { EI1: Integration with the regional and world economy } \\
\text { has a positive influence on the ability to apply IFRS }\end{array}$ & Ha and Nguyen (2018) \\
\hline & $\begin{array}{l}\text { EI2: Enterprises that are listed in foreign countries are } \\
\text { very likely to apply IFRS }\end{array}$ & Ha and Nguyen (2018) \\
\hline & $\begin{array}{l}\text { EI3: Enterprises with many commercial partners } \\
\text { applying IFRS are highly likely to apply }\end{array}$ & Simegn (2015) \\
\hline & $\begin{array}{l}\text { EI4: Enterprises owned by foreign investors can apply } \\
\text { IFRS }\end{array}$ & $\begin{array}{l}\text { Ha and Nguyen (2018), Al- } \\
\text { Absy and Ismail (2019) }\end{array}$ \\
\hline & $\begin{array}{l}\text { EI5: Enterprises with foreign loans are more likely to } \\
\text { apply IFRS }\end{array}$ & $\begin{array}{l}\text { Ha and Nguyen (2018); Al- } \\
\text { Absy and Ismail (2019) }\end{array}$ \\
\hline \multirow{5}{*}{$\begin{array}{l}\text { Accountants' } \\
\text { ability }\end{array}$} & $\begin{array}{l}\text { AA1: The qualifications of accountants affect the } \\
\text { application of IFRS }\end{array}$ & \multirow{5}{*}{ Al-Absy and Ismail (2019) } \\
\hline & $\begin{array}{l}\text { AA2: The accountant's work experience affects the } \\
\text { application of IFRS }\end{array}$ & \\
\hline & $\begin{array}{l}\text { AA3: Professional training of IFRS expertise for } \\
\text { accountants has an influence on the applicability of } \\
\text { this set of standards }\end{array}$ & \\
\hline & $\begin{array}{l}\text { AA4: The accounting staff's ability to read and } \\
\text { understand IFRS has a positive effect on the } \\
\text { applicability of this set of standards }\end{array}$ & \\
\hline & $\begin{array}{l}\text { AA5: The level of knowledge about IFRS affects the } \\
\text { applicability of IFRS }\end{array}$ & \\
\hline \multirow{5}{*}{$\begin{array}{l}\text { Possibility to } \\
\text { apply IFRS in } \\
\text { Vietnam } \\
\text { Stock Market } \\
\text { listed } \\
\text { companies }\end{array}$} & $\begin{array}{l}\text { PA1: The enterprise will selectively apply the contents } \\
\text { of IFRS }\end{array}$ & \multirow{2}{*}{ Albaskri (2015) } \\
\hline & $\begin{array}{l}\text { PA2: Enterprises will apply a step-by-step roadmap } \\
\text { from selective to full adoption of IFRS }\end{array}$ & \\
\hline & $\begin{array}{l}\text { PA3: The application of IFRS is very important for } \\
\text { businesses }\end{array}$ & Qualitative survey \\
\hline & $\begin{array}{l}\text { PA4: Listed companies are ready for the IFRS } \\
\text { application roadmap }\end{array}$ & Qualitative survey \\
\hline & $\begin{array}{l}\text { PA5: Enterprises are afraid of the change due to the } \\
\text { lack of easy access to market prices }\end{array}$ & Albaskri (2015) \\
\hline
\end{tabular}




\section{The results}

\subsection{Population characteristics}

\section{Table 2}

Sample characteristics

\begin{tabular}{|c|c|c|c|}
\hline Contruct & Classification & Number & Percentage \\
\hline \multirow{4}{*}{ Listing time } & Before 2005 & 5 & $1,80 \%$ \\
\hline & $2005-2010$ & 174 & $63,70 \%$ \\
\hline & $2011-2015$ & 25 & $9,20 \%$ \\
\hline & $2016-2020$ & 69 & $25,30 \%$ \\
\hline Total & & 273 & \\
\hline \multirow{4}{*}{$\begin{array}{l}\text { Scope of } \\
\text { business }\end{array}$} & Industry and construction & 147 & $53,85 \%$ \\
\hline & Trade and services & 50 & $18,32 \%$ \\
\hline & Agriculture, forestry and fisheries & 6 & $2,20 \%$ \\
\hline & Others & 70 & $25,64 \%$ \\
\hline Total & & 273 & \\
\hline \multirow{6}{*}{$\begin{array}{l}\text { Number of } \\
\text { employees }\end{array}$} & $<10$ & 35 & $12,82 \%$ \\
\hline & $10-50$ & 108 & $39,56 \%$ \\
\hline & $51-100$ & 68 & $24,91 \%$ \\
\hline & $101-200$ & 41 & $15,02 \%$ \\
\hline & $201-300$ & 13 & $4,76 \%$ \\
\hline & $>300$ & 8 & $2,93 \%$ \\
\hline Total & & 273 & \\
\hline \multirow{2}{*}{ Gender } & Male & 122 & $44,69 \%$ \\
\hline & Female & 151 & $55,31 \%$ \\
\hline Total & & 273 & \\
\hline \multirow{2}{*}{ Education } & Post - graduate & 76 & $38,58 \%$ \\
\hline & University & 197 & $100,00 \%$ \\
\hline Total & & 273 & \\
\hline \multirow{4}{*}{ Major } & Accounting and auditing & 149 & $54,58 \%$ \\
\hline & Finance - Banking & 88 & $32,23 \%$ \\
\hline & Business administration & 23 & $8,42 \%$ \\
\hline & Others & 13 & $4,76 \%$ \\
\hline Total & & 273 & \\
\hline \multirow{3}{*}{ Position } & Manager & 93 & $34,07 \%$ \\
\hline & Chief / Deputy of Accounting Department & 130 & $47,62 \%$ \\
\hline & $\mathrm{CFO}$ & 50 & $18,32 \%$ \\
\hline Total & & 273 & \\
\hline \multirow{4}{*}{ Working period } & $<2$ years & 9 & $3,30 \%$ \\
\hline & $2-5$ years & 32 & $11,72 \%$ \\
\hline & $5-10$ years & 73 & $26,74 \%$ \\
\hline & $>10$ years & 159 & $58,24 \%$ \\
\hline Total & & 273 & \\
\hline
\end{tabular}

Source: The research's data analysis 
Table 1 illustrates the demographic characteristics of the participants, including listing time, the scope of the business, number of employees, gender, major, position, working period. The remarkable point in the data is that the number of people who have been working for more than 10 years is the highest rate. The number of enterprises operating in the industry and construction sectors participating in the survey has a rate of $53.85 \%$.

\section{Table 3}

IFRS application situation, intention to be listed in foreign stock markets and level of IFRS application in Vietnam Stock Market listed companies

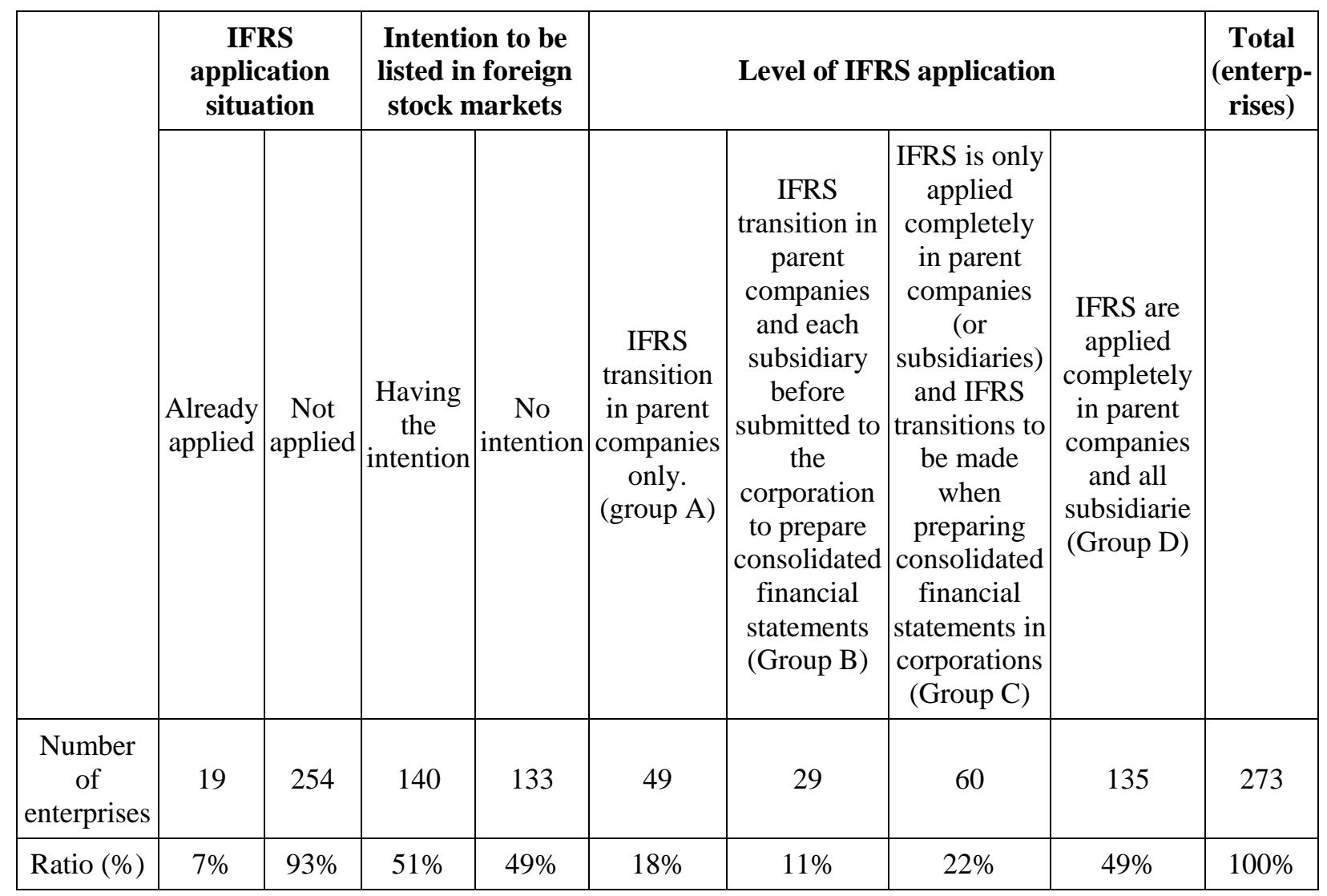

Source: Summarized from data surveyed

In 273 samples, there are $93 \%$ of companies that have never applied IFRS and 7\% have already applied. We can see that the number of listed non-financial companies applying IFRS is quite low. As for the intention to be listed in foreign stock markets, $51 \%$ of enterprises are positive and $49 \%$ negative. Considered under the level of IFRS application, we summarized from surveyed data to divide the enterprises into 4 groups with 4 levels of applying IFRS as shown in Table 1, the results are Group A: 18\%; Group B: 11\%; Group C: $22 \%$ and Group D has the highest proportion of $49 \%$. The results show that IFRS are applied completely in parent companies and all subsidiaries have the highest percentage.

\subsection{Scale reliability (internal validation of measurement scales)}

As Table 4 shows, most of the factors have Cronbach's Alpha indicators which are more than 0.6; corrected item-total correlation of the scales is higher than 0.3. After extracting 3 observed variants including C4 (qualified - accountant for IFRS recruitment is difficult), AA5 (accountants' ability) (many accountants are reluctant to adopt IFRS) and P5 (enterprises are hesitant because IFRS are principle-based), the 21 observed variants left are validated and used for EFA. 


\section{Table 4}

Cronbach's Alpha indicators

\begin{tabular}{|c|c|c|c|c|}
\hline \multirow{2}{*}{ Scale } & \multicolumn{2}{|c|}{ Number of variants } & \multirow{2}{*}{ Cronbach's Alpha } & \multirow{2}{*}{$\begin{array}{c}\text { Minimum corrected item-total } \\
\text { correlation }\end{array}$} \\
\hline & Before & After & & \\
\hline Manager attitudes (MA) & 4 & 4 & .812 & .613 \\
\hline Cost $(\mathrm{C})$ & 5 & 4 & .861 & .667 \\
\hline Economic integration (EI) & 5 & 5 & .889 & .697 \\
\hline $\begin{array}{l}\text { Ability of accountants } \\
\text { (AA) }\end{array}$ & 5 & 4 & .801 & .558 \\
\hline $\begin{array}{l}\text { Possibility to apply IFRS } \\
\text { (P) }\end{array}$ & 5 & 4 & .874 & .672 \\
\hline
\end{tabular}

Source: Data analysis result of the research with SPSS 22.0

Using EFA with the Principle Component Analysis extraction method and orthogonal rotation (Varimax), the analysis includes 17 observed variants of EFA shown in Table 3, with the KMO test for sampling at 0.856, Barlett's Test returns the Sig $=0.000$; the factors extracted are 4, thus all are compliant with the theoretical model we built. Cumulative variance is $70.316 \%$, and the total variance explained by each component is always bigger than 0.5. So, EFA is suitable for data and observed variables that have a correlation in the population and is used for the next analysis.

\section{Table 5}

Independent variable EFA

\section{Rotated Component Matrix ${ }^{\text {a }}$}

\begin{tabular}{|c|c|c|c|c|}
\hline & & Comp & & \\
\hline & 1 & 2 & 3 & 4 \\
\hline EI5 & .832 & & & \\
\hline EI1 & .828 & & & \\
\hline EI3 & .785 & & & \\
\hline EI2 & .774 & & & \\
\hline $\mathrm{C} 2$ & & .825 & & \\
\hline $\mathrm{C} 1$ & & .825 & & \\
\hline C3 & & .762 & & \\
\hline C5 & & .735 & & \\
\hline P3 & & & .795 & \\
\hline P2 & & & .783 & \\
\hline P1 & & & .766 & \\
\hline P4 & & & .755 & \\
\hline AA3 & & & & .866 \\
\hline AA2 & & & & .815 \\
\hline AA1 & & & & .793 \\
\hline
\end{tabular}

Extraction Method: Principal Component Analysis

Rotation Method: Varimax with Kaiser Normalization

a. Rotation converged in 5 iterations.

Source: Data analysis result of the research with SPSS 22.0 


\subsection{Correlation test}

Table 6 shows the correlation coefficients of variables, the aim of this correlation analysis is to check the correlation of independent and independent variables to take out the components that may lead to multicollinearity before regression analysis. All the independent variables have Sig $<5 \%$, so they are all have correlations with the dependent variables. The coefficients of the 4 factors are: MA: 0.045, C: 0.732, EI: 0.518, AA: 0.396. The coefficients of independent variables in the model do not exceed 0.8, so in the regression model, there will be little chance for multicollinearity to take place. This proves that dependent variables have linear correlations with the 4 factors, and they have a normal distribution.

\section{Table 6}

Correlation matrix

\section{Correlations}

\begin{tabular}{|c|c|c|c|c|c|c|}
\hline & & $\mathbf{P}$ & MA & $\mathbf{C}$ & EI & $\mathbf{A A}$ \\
\hline \multirow[t]{3}{*}{$\mathrm{P}$} & $\begin{array}{l}\text { Pearson } \\
\text { Correlation }\end{array}$ & 1 & $.406^{* * *}$ & $-.732^{* *}$ & $.518^{* *}$ & $.396^{* * *}$ \\
\hline & Sig. (2-tailed) & & .000 & .000 & .000 & .000 \\
\hline & $\mathrm{N}$ & & 273 & 273 & 273 & 273 \\
\hline \multirow[t]{3}{*}{ MA } & $\begin{array}{l}\text { Pearson } \\
\text { Correlation }\end{array}$ & & 1 & $-.408^{* * *}$ & $.318^{* *}$ & $.236^{* * *}$ \\
\hline & Sig. (2-tailed) & & & .000 & .000 & .000 \\
\hline & $\mathrm{N}$ & & & 273 & 273 & 273 \\
\hline \multirow[t]{3}{*}{$\mathrm{C}$} & $\begin{array}{l}\text { Pearson } \\
\text { Correlation }\end{array}$ & & & 1 & $-.514^{* *}$ & $-.296^{* *}$ \\
\hline & Sig. (2-tailed) & & & & .000 & .000 \\
\hline & $\mathrm{N}$ & & & & 273 & 273 \\
\hline \multirow[t]{3}{*}{ EI } & $\begin{array}{l}\text { Pearson } \\
\text { Correlation }\end{array}$ & & & & 1 & $.292^{* *}$ \\
\hline & Sig. (2-tailed) & & & & & .000 \\
\hline & $\mathrm{N}$ & & & & & 273 \\
\hline \multirow[t]{3}{*}{ AA } & $\begin{array}{l}\text { Pearson } \\
\text { Correlation }\end{array}$ & & & & & 1 \\
\hline & Sig. (2-tailed) & & & & & \\
\hline & $\mathrm{N}$ & & & & & \\
\hline
\end{tabular}

**. Correlation is significant at the 0.01 level (2-tailed)

Source: Data analysis result of the research with SPSS 22.0

\subsection{Multivariate linear regression analysis}

To identify, measure and evaluate the possibility to apply IFRS in Vietnam Stock Market listed companies, the author use a multivariate linear regression method with 4 factors extracted from the EFA mentioned above. 


\section{Table 7}

Multivariate linear regression analysis results

\begin{tabular}{|c|c|c|c|c|c|c|c|}
\hline & \multicolumn{2}{|c|}{$\begin{array}{l}\text { Unstandardized } \\
\text { Coefficients }\end{array}$} & \multirow{2}{*}{$\begin{array}{c}\begin{array}{c}\text { Standardized } \\
\text { coefficients }\end{array} \\
\text { Beta } \\
\end{array}$} & \multirow[t]{2}{*}{$\mathbf{t}$} & \multirow[t]{2}{*}{ Sig } & \multicolumn{2}{|c|}{ Collinearity Statistics } \\
\hline & Beta & $\begin{array}{l}\text { Standard } \\
\text { deviation }\end{array}$ & & & & Tolerance & VIF \\
\hline Constant & 3.424 & .290 & & 11.805 & .000 & & \\
\hline MA & .099 & .049 & .087 & 2.007 & .046 & .807 & 1.239 \\
\hline $\mathrm{C}$ & -.417 & .035 & -.572 & -11.935 & .000 & .656 & 1.524 \\
\hline EI & .114 & .036 & .148 & 3.204 & .002 & .704 & 1.420 \\
\hline AA & .146 & .037 & .163 & 3.913 & .000 & .875 & 1.143 \\
\hline \multicolumn{5}{|l|}{$\mathrm{R}^{2}$} & \multicolumn{3}{|c|}{0.595} \\
\hline \multicolumn{5}{|c|}{\begin{tabular}{|l} 
Adjusted $\mathrm{R}^{2}$ \\
\end{tabular}} & \multicolumn{3}{|c|}{0.589} \\
\hline \multicolumn{5}{|c|}{ Sig. F Change } & \multicolumn{3}{|c|}{0.000} \\
\hline \multicolumn{5}{|c|}{ Durbin-Watson } & \multicolumn{3}{|c|}{2.090} \\
\hline
\end{tabular}

Source: Data analysis result of the research with SPSS 22.0

Table 5 shows that $\mathrm{R}^{2}=0,595$; the value of $\mathrm{R}^{2}$ demonstrates that the independent variables used in the model can explain $59.5 \%$ of the change independent variables, the $40.5 \%$ left are the factors left out. The results also let us know that VIF (variance inflation factor) is very small, all of them are less than 2, so multicollinearity does not occur. For the independence of residuals test, the Durbin-Watson statistics is $2.090<3$, showing that there is no serial autocorrelation, or the estimated residuals of the independent model have no linear correlation. The $t$ value in accordance with Sig. of independent variables are all less than 0.05 , so they have no statistical meaning. Table 6 shows that all the 4 observed variables affect the possibility to apply IFRS. Three of them, having relationships in the same direction, are: manager attitudes, economic integration, accountants' ability and the other one is cost, which has an opposite direction. The standardized regression coefficient equation is as follows:

$$
\mathrm{Y}=0.099 \mathrm{X}_{1}-0.417 \mathrm{X}_{2}+0.114 \mathrm{X}_{3}+0.146 \mathrm{X}_{4}+3.424
$$

Where:

Y: possibility to apply IFRS in Vietnam Stock Market listed companies

$\mathrm{X}_{1}$ : manager attitudes

$\mathrm{X}_{2}$ : costs

$\mathrm{X}_{3}$ : economic integration

$\mathrm{X}_{4}$ : accountants' ability

Table 8

Summary of the factorial impact in the possibility to apply IFRS

\begin{tabular}{|c|l|c|c|}
\hline $\mathbf{N}^{\mathbf{0}}$ & \multicolumn{1}{|c|}{ Factor } & Value & Percentage \\
\hline 1 & MA: Manager attitudes & 0.099 & $12.76 \%$ \\
\hline 2 & C: Costs & 0.417 & $53.74 \%$ \\
\hline 3 & EI: Economic integration & 0.114 & $14.69 \%$ \\
\hline 4 & AA: Accountants' ability & 0.146 & $18.81 \%$ \\
\hline & & $\mathbf{0 . 7 7 6}$ & $\mathbf{1 0 0 \%}$ \\
\hline
\end{tabular}

Source: Data analysis result of the research with SPSS 22.0 
In Table 8, among the influencing factors, the cost has the strongest effect and the opposite direction on the ability to apply IFRS, specifically: C: cost, takes 53.74\%; second: Accountants' ability, takes $18.81 \%$, third comes economic integration factor, takes $14.69 \%$ to the possibility to apply IFRS and last comes manager attitude factor, with $12.76 \%$.

\section{Conclusion}

\subsection{Conclusion}

The article analyzes and identifies 3 positive factors and one negative that place impacts on the possibility of applying IFRS in non-financial enterprises listed in the Vietnam Stock Market. They are manager attitudes, costs, economic integration and accountants' ability. With this paper, the author hope to help administrators and policy planners have more specific concepts about the above issues and have better solutions in the coming time, giving better conditions for enterprises to apply IFRS more swiftly and successfully.

\subsection{Policy implication}

Costs, the factor that places the most important impact on the possibility of the application of IFRS, can be easily identified. The higher the initial cost of investment, the bigger the obstacles for enterprises to adapt to IFRS implementation. To cut costs for companies, experts from professional organizations must be involved, they can give good help on IFRS implementation, ensuring the "do right the first time" for enterprises in meeting IFRS requirements.

Furthermore, accountants' knowledge of IFRS is another factor determining the success of IFRS application. If the knowledge in IFRS is widely updated among those staff, the IFRS implementation will no more give difficulties for enterprises.

Additionally, the economic integration also pushes the possibility to apply IFRS. Graceful governmental policies to encourage international business activities also give benefits to the implementation of IFRS in Vietnamese enterprises.

Lastly, the manager's attitude should be changed and updated towards IFRS adaptation. The more positive the attitude they have, the better chance for IFRS to be applied. So, it is important for policymakers to make business managers understand their benefits and responsibilities in IFRS implementation.

\section{References}

Ajzen, I. (1991). The theory of planned behavior. Organizational Behavior and Human Decision Processes, 50(2), 179-211.

Al-Absy, M. S. M., \& Ismail, K. N. I. K. (2019). Accountants perception on the factors affecting the adoption of international financial reporting standards in Yemen. International Journal of Financial Research, 10(4), 128-142.

Albaskri, I. K. M. (2015). The perception of accountants on IFRS adoption: Evidence from Libya (Unpublished master's thesis). University Utara Malaysia, Malaysia.

Bananuka, J., Kadaali, A. W., Mukyala, V., Muramuzi, B., \& Namusobya, Z. (2019). Audit committee effectiveness, isomorphic forces, managerial attitude and adoption of international financial reporting standards. Journal of Accounting in Emerging Economies, 9(4), 502-526. 
Bananuka, J., Tumwebaze, Z., Musimenta, D., \& Nuwagaba, P. (2019). Determinants of adoption of international financial reporting standards in Ugandan micro finance institutions. African Journal of Economic and Management Studies, 10(3), 336-355.

Baruni, W., \& Sentosa, I. (2014). The effect of economic factors and stock market in implementing the IAS in Libya. International Journal of Business and Management Invention, 2(10), 32-44.

Bassemir, M. (2018). Why do private firms adopt IFRS? Accounting and Business Research, 48(3), 237-263.

Bhattacharyya, A. (2014). Managerial attitude and support for social responsibility through the lens of legitimacy theory-a cross country comparison. Social Responsibility Journal, 10(4), 716-736.

Boateng, A. A., Arhin, A. B., \& Afful, V. (2014). International financial reporting standard's (IFRS) adoption in Ghana: Rationael, benefits and challenges. Journal of Advocacy, Research and Education, 1(1), 26-32.

Boumediene, S. L., Zarrouk, R., \& Tanazefti, I. (2016). Obstacles to the adoption of the IAS/IFRS in Tunisia. Journal of Applied Business Research, 32(3), 621-636.

Bui, N. T., Chuc, T. A., \& Le, O. T. T. (2020). The implication of applying IFRS in Vietnamese enterprises from an expert perspective. Management Science Letters, 10(3), 551-564.

Choi, F. D., \& Meek, G. (2008). International accounting (7th ed.). Upper Saddle River, NJ: Pearson Education Inc.

Christopher, N., \& Parker, R. B. (2016). Comparative international accounting (13th ed.). Edinburgh Gate, England: Pearson Education Limited.

Djatej, A., Zhou, D., Gorton, D., \& McGonigle, W. (2012). Critical factors of IFRS adoption in the US: An empirical study. Journal of Finance and Accountancy, 9(1), 1-14.

Ha, T. X., \& Nguyen, H. N. (2018). Factors affecting the transion from Vietnamese accounting standards to IFRS in financial statements. Foreign Economic Magazine, 102, 1-19.

Judge, W., Li, S., \& Pinsker, R. (2010). National adoption of international accounting standards: An institutional perspective. Corporate Governance: An International Review, 18(3), 161-174.

Kossentini, A., \& Othman, H. (2014). A study of the institutional and economic determinants of IFRS adoption in emerging economies. Paper presented at the TIJA Symposium TIJA, VK Zimmerman Center for International Education \& Research in Accounting, University of Illinois at Urbana-Champaign, IL.

Lasmin, R. (2011). An institutional perspective on international financial reporting standards adoption in developing countries. Academy of Accounting and Financial Studies Journal, 15(2), 61-71.

Ministry of Finance. (2020). Decision 345/QD-BTC - Approving scheme for application of financial reporting standards in Vietnam. Ministry of finance. Retrieved August 20, 2020, from http://ifrs.vn/document/quyet-dinh-345-2020-7379/

Misırlığlu, İ. U., Tucker, J., \& Yükseltürk, O. (2013). Does mandatory adoption of IFRS guarantee compliance? The International Journal of Accounting, 48(3), 327-363. 
Nguyen, P. C., \& Nguyen, T. D. K. (2012). International harmonization and national particularities of accounting: Recent accounting development in Vietnam. Journal of Accounting \& Organizational Change, 8(3), 431-451.

Oppong, C., \& Aga, M. (2019). Economic growth in European Union: Does IFRS mandatory adoption matter? International Journal of Emerging Markets, 14(5), 792-808.

Rogers, E. M. (2010). Diffusion of innovations (4th ed.). New York, NY: Simon and Schuster.

Shima, K. M., \& Yang, D. C. (2012). Factors affecting the adoption of IFRS. International Journal of Business, 17(3), $276-298$.

Simegn, Y. (2015). Adoption of International Financial Reporting Standards (IFRS) in Ethiopia: Empirical evidence. The International Journal Research Publication's Research Journal of Economics and Business Studies, 4(3), 1-20.

Tran, T. Q. (2016). Factors that affect the application of international standards in for accounting in countries. Retrieved August 20, 2020, from http://ifrsvietnam.vn/tin-tuc/nghien-cuu-traodoi-72/nhung-nhan-to-tac-dong-den-viec-ap-dung-chuan-muc-quoc-te-ve-ke-toan-tai-cacquoc-gia-191.html

Tyrrall, D., Woodward, D., \& Rakhimbekova, A. (2007). The relevance of international financial reporting standards to a developing country: Evidence from Kazakhstan. The International Journal of Accounting, 42(1), 82-110. 